Marta Ficoń

Instytut Teologiczny im. św. Jana Kantego w Bielsku-Białej

\title{
Los dzieci zmarłych bez chrztu \\ - nieznana historia i współczesne pytania
}

W dobie aborcji na życzenie i niekontrolowanej manipulacji embrionami jedną z najbardziej pilnych trosk Kościoła stało się pytanie o zbawienie najmniejszych członków rodzaju ludzkiego zmarłych bez sakramentu odrodzenia oraz o jego egzystencjalne konsekwencje. Widocznym efektem tej troski stał się wydany w 2007 roku dokument Międzynarodowej Komisji Teologicznej pt. Nadzieja zbawienia dla dzieci zmarlych bez chrztu oraz liczne zmiany liturgiczne, a także przekształcenia w zakresie prawa kanonicznego. Temat ten był wielokrotnie podejmowany w publikacjach teologicznych, których autorzy starali się z każdej możliwej perspektywy spojrzeć na ten arcyciekawy problem ${ }^{1}$. Pomimo watykańskiego dokumentu oraz pozytywnych przemian na polu zarówno życiowych, jak i czysto teoretycznych zmagań z tym tematem nie został on wyczerpująco zgłębiony i definitywnie zamknięty. Współcześnie nadal pojawiają się pytania, na które teologowie próbują dostarczyć odpowiedzi.

Na płaszczyźnie teologicznej związane jest to z zagadnieniem uzasadnienia nadziei na zbawienie nieochrzczonych dzieci, obecnym $\mathrm{w}$ dokumencie Międzynarodowej Komisji Teologicznej. Tematy, które wymaga-

Bardziej szczegółową i dokładną analizę tego problemu w dziejach Kościoła można znaleźć w pozycji: M. Ficoń, Od piekła do nadziei zbawienia. Rozwój kwestii zbawienia dzieci zmarłych bez chrztu świętego w teologii katolickiej i jej egzystencjalna doniosłość, Kraków 2012. 
ją dodatkowych badań, dotyczą między innymi solidarności Chrystusa z całą ludzkością oraz martyrologicznego aspektu aborcji. Oprócz tego istnieją również takie pytania, jak na przykład: dlaczego Kościół doszedł do dobrej nowiny o nadziei zbawienia tych dzieci dopiero teraz? Dlaczego przez tyle lat podtrzymywał naukę o ich potępieniu albo w ognistym piekle (Augustyn, Fulgencjusz z Ruspe) albo w mrocznym limbusie (Tomasz z Akwinu)?

Z kolei na płaszczyźnie egzystencjalnej, która posiada bardzo niechlubną historię ze względu na wytworzenie się wielu zachowań i praktyk pseudoreligijnych, magicznych bądź wręcz nieludzkich, do dziś pokutują myślenie i postępowanie, które nie przystoją chrześcijanom. Chodzi przede wszystkim o zabobony związane z chrztem, brak duszpasterskiej delikatności i obycia wobec rodziców, którzy stracili swe pociechy przed chrztem oraz problemy związane z ich pogrzebem.

W celu znalezienia odpowiedzi na powyższe pytania należy pokrótce prześledzić każdą z tych płaszczyzn, poczynając od źródeł wspomnianych problemów obecnych w historii, a kończąc na współczesnym ujęciu i próbie ich rozwiązania.

\section{A. Wymiar teologiczny kwestii}

Każdy, kto choć trochę interesował się tym tematem, pamięta, iż na przestrzeni wieków wykształciły się trzy główne modele podejścia do losu wiecznego małych nieochrzczonych dzieci, które nie dorosły do używania rozumu.

\section{Trzy perspektywy}

Pierwszy z nich zyskał konkretne kształty w V wieku, kiedy Augustyn z Hippony przedstawił naukę o poena mitissima, czyli najmniejszej możliwej karze dla takich istot w płomieniach piekła i w towarzystwie demonów. Przez pierwsze cztery wieki chrześcijaństwa dyskusja o losie tych dzieci praktycznie nie istniała ze względu na nie do końca wyjaśnioną naturę grzechu pierworodnego. Refleksja teologiczna nie wyszła poza ramy upomnień duszpasterzy, by udzielać chrztu także małym dzieciom, i poza 
ostrzeżenia o mrocznej przyszłości nieochrzczonych². Pod koniec IV wieku zarówno na Wschodzie, jak i na Zachodzie chrześcijańskiego świata dominowała neutralna teza o niepewnym stanie takich dzieci po śmierci, bowiem twierdzono, iż nie otrzymają ani kary w ognistym piekle, ani nie dostąpią nagrody w chwale nieba ${ }^{3}$. Dopiero w ferworze apologetycznej walki Augustyna z pelagianami o skutki nieodpuszczonego grzechu pierworodnego przez sakrament chrztu świętego w Kościele Zachodnim rozprzestrzeniła się teza o ich potępieniu i wiecznych cierpieniach z dala od Boga. Taka konstatacja biskupa Hippony wynikała z jego rozumienia grzechu pierworodnego jako zbrodni popełnionej przez wszystkich ludzi w Adamie i przez to niosącej z sobą najgorszą możliwą sankcję. Ograniczył on również dostępność łaski Bożej dla tych dzieci tylko i wyłącznie do sakramentu chrztu przyjętego in $r^{4}$. Na jego przekonania miały też wpływ niespokojne czasy, w których żył i tworzył, kreując środowisko, w którym jakakolwiek inna wersja nauki o losie nieochrzczonych dzieci nie miała racji bytu ze względu na twardą politykę wobec heretyków odrzucających potrzebę chrzczenia dzieci „na odpuszczenie grzechów”. Wielki autorytet biskupa Hippony i poparcie jego nauki przez wielu teologów (także papieży) spowodowały, iż radykalne podejście do możliwości zbawienia tych najmniejszych przetrwało do XII wieku, kiedy to wytworzył się kolejny model postrzegania problemu.

Bazując na pismach Anzelma z Canterbury, który pod wpływem nauki Pseudo-Dionizego Areopagity określił grzech pierworodny jako brak łaski, a nie obecność czegoś złego w człowieku, Piotr Abelard stwierdził

Zob. Ireneusz z Lyonu, Contre les hérésies II 22, 4, SC 293, s. 220-223; Cyprian z Kartaginy, List LXIV 5, [w:] Acta Synodalia ann. 50-381, oprac. A. Baron, H. Pietras, Kraków 2006, s. 12-15; Syrycjusz, Epistola I ad Himerium episcopum 2, 3, PL 13, kol. 1135 (DS 184).

Zob. Grzegorz z Nyssy, O dzieciach przedwcześnie zmarłych 68, [w:] Bóg i zło. Pisma Bazylego Wielkiego, Grzegorza z Nyssy i Jana Chryzostoma, oprac. J. Naumowicz, Kraków 2003, s. 86 (PG 46, kol. 192); Grzegorz z Nazjanzu, Discours sur le baptême XL 23, SC 358, s. 247-248; Ambroży z Mediolanu, De Abraham II 84, PL 14, kol. 521; Augustyn z Hippony, De libero arbitrio III 23, 66, PL 32, kol. 1303-1304.

Zob. Augustyn z Hippony, De natura et gratia 3, PL 44, kol. 249; De peccatorum meritis et remissione et de baptismo parvulorum I 21, PL 44, kol. 120: „Infantes non baptizati lenissime quidem, sed tamen damnantur. [...] Potest proinde recte dici, parvulos sine baptismo de corpore exeuntes in damnatione omnium mitissima futuros"; De natura et gratia 9, PL 44, kol. 251; Epistola CLXXXVI 29, PL 33, kol. 826; De anima et eius origine III 12, PL 44, kol. 516; Contra Iulianum V 44, PL 44, kol. 809; Contra secundam Iuliani responsionem imperfectum opus II 105, PL 45, kol. 1185; II 161, PL 45, kol. 1210; III 199, PL 45, kol. 1333. 
w Komentarzu do Listu do Rzymian, że kara za niego nie powinna być dotkliwa i boleśnie odczuwalna. Skoro grzech pierworodny jest prostym brakiem łaski, a nie winą osiągniętą przez osobiste przewinienia, to taka też powinna być kara za niego, polegająca na przebywaniu w mroku Bożej nieobecności bez jakiejkolwiek nadziei na zmianę tej kondycji ${ }^{5}$. Odkąd teza Abelarda o potępieniu bez dodatkowych cierpień została potwierdzona przez mistrza Sentencji Piotra Lombarda słowami: „nie będą doświadczać żadnej kary materialnego ognia czy robaka sumienia, poza tym, że będzie im na wieki brakowało oglądania Boga", rozprzestrzeniła się ona po europejskich uniwersytetach. Stała się również fundamentem dla hipotezy limbus puerorum, mającej protagonistów w osobach Aleksandra z Hales, Bonawentury, Alberta Wielkiego, a zwłaszcza Tomasza z Akwinu, który nadał temu pojęciu dokładną charakterystykę.

„Otchłań dzieci” była pojęciem określającym zewnętrzną część piekła, w której miały znajdować się dzieci zmarłe bez chrztu z powodu nieodpuszczonego przez sakrament odrodzenia grzechu pierworodnego. Pośród innych części zaświatów wyróżniała się tym, że nie było w nim poena sensus, a tylko poena damni, czyli brak widzenia Boga ${ }^{7}$. Przez długi czas, aż do pierwszej części XX wieku, teoria ta wydawała się teologom najlepszym rozwiązaniem wspomnianej kwestii, pomijając wszelkie zawirowania związane z odrodzeniem się tezy Augustyna o poena mitissima (Grzegorz z Rimini, spór jezuitów z augustianami w XVIII wieku w kontekście kontrowersji jansenistycznej) czy powstaniu teorii „miłosiernych” szukających rozwiązań umożliwiających zbawienie dzieciom pozbawionym obmycia odradzające-

5 Zob. Piotr Abelard, Expositio in Epistolam ad Romanos 5, 19, Freiburg 2000, t. 2, s. 410; 422-424.

6 Piotr Lombard, Sententiarum libri quatuor, lib. II, dist. 33, 5, PL 192, kol. 730: „pro originali [peccato] quod a parentibus trahitur, parvuli damnabuntur; pro eo nullam aliam ignis materialis vel conscientiae vermis poenam sensuri, nisi quod Dei visione carebunt in perpetuum".

Zob. Aleksander z Hales, Summa Theologica II/II, inq. 2, tract. 3, q. 2, membr.10, cap. 1, Florentiae 1930, t. 3, s. 267; Bonawentura, In IV Sententiarum, d. 45, a. 1, q. 1, [w:] tegoż, Opera omnia, Parisiis 1866, t. 6, s. 511; Albert Wielki, Commentarii in III librum Sententiarum, d. 22, a. 4, sol., [w:] tegoż, Opera omnia, Parisiis 1894, vol. 28, s. 392; Commentarii in IV librum Sententiarum, d. 1, a. 20, ad 1.3, [w:] tegoż, Opera omnia, Parisiis 1894, vol. 29, s. 36; Tomasz z Akwinu, Commentum in lib. III Sententiarum, d. 22, q. 2, a. 1, sol. 2; De malo, q. 5, a. 1, resp.; Suma Teologiczna suppl., q. 101, a. 1, resp.; Commentum in lib. II Sententiarum, d. 33, q. 2, a. 1, sol.: „Et ideo nulla alia poena sibi debetur nisi privatio illius finis ad quem donum subtractum ordinabat; ad quod per se natura humana attingere non potest. Hoc autem est divina visio; et ideo carentia hujus visionis est propria et sola poena originalis peccati post mortem". 
go (kard. Kajetan, I. L. Bianchi, H. Schell, H. Klee)ํ. Ten drugi nurt w teologii związany był z możliwościami, jakie Tomasz z Akwinu odkrył dzięki stwierdzeniu: „Bóg nie związał aż tak swojej mocy, żeby bez sakramentów nie mógł udzielić skutku sakramentów"9. Uświadomiono sobie przez to, że łaska Boża nie musi koniecznie i bezwzględnie ograniczać się do chrztu przyjętego in re, zwłaszcza w przypadku, gdy osoba nie jest w żaden sposób winna tego, że nie otrzymała tego sakramentu.

Pomijając różne próby ratowania dzieci za pomocą teorii o braku ograniczeń dla Bożej wszechmocy względem nich, teologowie przez osiem wieków roztaczali wizję otchłani, w której najmniejsi nie tylko pozbawieni byli Bożej obecności, ale też - w niektórych wariantach tej teorii - cieszyli się szczęściem naturalnym, niemającym nic wspólnego z nadprzyrodzonością, a nawet mieli zamieszkać po Sądzie Ostatecznym na odnowionej przez ogień Ziemi, gdzie wzdychaliby wiecznie do niebiańskich rozkoszy, radując się jednocześnie wszystkimi doskonałościami dostosowanymi do ich ograniczonej natury ${ }^{10}$.

Z nastaniem wieku XX okazało się, że pojęcie limbus puerorum jest rozwiązaniem niewystarczającym. Klimat narastającej ilości pytań o zasięg Bożego miłosierdzia, o Jego wolę zbawienia wszystkich ludzi, zwłaszcza tych najmniejszych i najbardziej bezbronnych oraz o możliwości zbawienia pozasa-

8 Kard. Kajetan głosił teorię votum parentum, czyli możliwość zbawienia dziecka, któremu nie da się udzielić chrztu, dzięki modlitwom rodziców, zob. Thomas de Vio Caietanus, In III Sent., q. 68, a. 2; 11, [w:] Sancti Thomae Aquinatis opera omnia iussu Leonis XIII P. M. edita cum Commentariis Thomae de Vio Caietani ordinis Praedicatorum, Romae 1906, vol. 12; I. L. Bianchi opracował hipotezę o pragnieniu chrztu dziecka wyrażonego w jego imieniu przez matkę, zob. I. L. Bianchi, De remedio aeternae salutis pro parvulis in utero clausis sine baptismate decedentibus, prop. 3, nr 3; prop. 4, nr 1, [w:] tegoż, Dissertationes tres, Venetiis 1770, s. 178-181; 232-233; H. Schell stworzył teorię „,chrztu cierpienia” i śmierci jako „pseudosakramentu”, zob. H. Schell, Katholische Dogmatik, Paderborn 1893, t. 3, cz. 2, s. 479-480; H. Klee przedstawił bardzo popularną w swoim czasie tezę o oświeceniu w momencie śmierci, kiedy dziecko nabywa zdolności do wyboru między Bogiem a potępieniem, czyli jest zdolne do chrztu pragnienia, zob. H. Klee, Katholische Dogmatik, Mainz 1861, s. 646.

Tomasz z Akwinu, Suma Teologiczna III, q. 64, a. 7, resp.: „Deus virtutem suam non alligavit sacramentis quin possit sine sacramentis effectum sacramentorum conferre”.

10 Zob. Ambrosius Catharinus Politi, De statu futuro puerorum sine sacramento decedentium, [w:] tegoż, Opuscula, Lugduni 1542, s. 150-168; A. Pighius, Controversiarum praecipuarum in comitiis Ratisponensibus tractatarum, De peccato originis controversia prima, Coloniae 1542; H. Savonarola, Triompho della Croce di Christo III 9, Venetia 1547, s. 61-64; F. Suarez, Commentariorum ac disputationum in Tertiam partem Divi Thomae, q. 56, a. 2, d. 50, sect. 5; q. 59, a. 6, d. 57, sect. 6; d. 58, sect. 3, Moguntiae 1616, t. 2, s. 580-582; 681-682; 697-698. 
kramentalnego doprowadził niektórych teologów do szukania rozstrzygnięć, które usiłowały „ratować” te dzieci przed otchłanią, próbując jednocześnie nie odbiegać od nauki Kościoła. Okazało się to niezwykle trudnym zadaniem, ponieważ długa tradycja nauczania o niezbawieniu nieochrzczonych nie dawała prawie wcale pola do manewru. Te dążenia ujawniły się ze zdwojoną siłą po II wojnie światowej, kiedy to E. Boudes przedstawił teorię o votum Ecclesiae, C. V. Héris przypomniał teorię votum parentum, zaś G. Mulders wypracował tezę o votum inconscium i zarodku wiary obecnym w każdym człowieku ${ }^{11}$. Dosyć duża grupa zwolenników rozwiązań „miłosiernych” optowała za teorią oświecenia, rozbudowaną w XIX wieku przez H. Klee ${ }^{12}$.

Polemika między tradycjonalistami, niewidzącymi innej możliwości dla nieochrzczonych dzieci jak tylko brak oglądania Boga w limbus puerorum, a sympatykami rozstrzygnięć „,szerokich" przybrała niezwykle dynamiczny obrót przed Soborem Watykańskim II. Pierwsi twierdzili, że długa tradycja teologiczna każe uznać naukę o otchłani dzieci za twierdzenie de fide, potwierdzone przez sobory w Lyonie i we Florencji ${ }^{13}$. Drudzy udowadniali, że orzeczenia soborowe nie dotyczą losu tych dzieci, a przyznawanie pojęciu limbusu waloru dogmatu jest za daleko idącą nadinterpretacją i niewłaściwym położeniem akcentów w nauce o konieczności sakramentu chrztu i Kościoła do zbawienia ${ }^{14}$.

11 Zob. E. Boudes, Réflexions sur la solidarité des hommes avec le Christ, „Nouvelle Revue Théologique” 71 (1949), z. 6, s. 602-605; C. V. Héris, Le salut des enfants morts sans baptême, „MaisonDieu” 10 (1947), s. 103-104; G. Mulders, Rond het Limbus vraagstuk, „Bijdragen” 9 (1948), s. 240-244.

12 Zob. P. R. Pies, Die Heilsfrage der Heiden, Aachen 1925, s. 172-176; D. Feuling, Katholische Glaubenslehre. Einführung in das theologische Leben für weitere Kreise, Salzburg 1937, s. 725; A. Janssens, Doopsel en vormsel, Kortijk 1938, s. 14-16; 68-74; M. Bäuerle, Das Heil der ohne Taufe verstorbenen Kinder, „Theologie und Glaube” 27 (1935), z. 6, s. 727-739; J. García-Plaza de San Luis, Existe el limbo de los niños?, „Revista Eclesiastica” 10 (1936), s. 113, 140; P. Gumpel, Unbaptized infants: May they be saved?, „The Downside Review” 230 (72) 1954, s. 360-361; G. M. Fangauer, Fate of unbaptized infants, „The Homiletic and Pastoral Review” 46 (1946), s. 854; 47(1946), s. 11; 14.

13 Por. II Sobór Lyoński, Professio fidei Michaelis Palaeologi imperatoris, DS 858: „Illorum autem animas, qui in mortali peccato vel cum solo originali decedunt, mox in infernum descendere, poenis tamen disparibus puniendas"; Sobór Florencki, Bulla unii z Grekami „Laetentur caeli” 16, [w:] Dokumenty Soborów Powszechnych (1414-1445). Konstancja, Bazylea-Ferrara-Florencja-Rzym, oprac. A. Baron, H. Pietras, Kraków 2007, t. 3, s. 474-475; J. F. Sagüés, Sacrae theologiae summa. De Deo uno et trino. De Deo creante et elevante. De peccatis, Matriti 1958, t. 2, s. 971; A. Michel, L'existence des limbes n'est-elle pas un article de foi?, „L'Ami du Clergé” 24 (61) 1951, s. 375-378.

14 Zob. J. Galot, La salvezza dei bambini morti senza battesimo, „La Civiltà Cattolica” 2 (122) 1971, z. 3, s. 233; F. Wawrzyniak, Zbawienie wieczne nie ochrzczonych małych dzieci, Poznań 1979, s. 152-161; 
Ze względu na niedoskonałość dyskusji w tej kwestii, liczne argumenty nieprzychylne nauce klasycznej oraz jej niezgodność z rozwojem sensus fidelium Główna Komisja Przygotowawcza Vaticanum II nie włączyła jej do programu obrad, pozostawiając teologom do dalszych badań. Sobór określił jednak zasady wyznaczające horyzont, ku któremu zmierzała dyskusja na ten temat. Wyeksponował przede wszystkim nadrzędną wartość powszechnej woli zbawczej Boga i powołanie każdego człowieka do udziału w Jego nadprzyrodzonym życiu, podkreślając, że „Duch Święty wszystkim daje możliwość uczestniczenia w tym misterium paschalnym w tylko Bogu znany sposób" (KDK 22). W teologicznych dywagacjach dla nieochrzczonych zmarłych dzieci zajaśniała w końcu nadzieja na możliwość zbawienia, poparta soborową nauką o kręgach przynależności do Kościoła (zob. KK 13-16), poza którym nie ma zbawienia.

Refleksja na ten temat, rozwijana w nielicznych w porównaniu z okresem przedsoborowym publikacjach, podążyła ku trzeciemu modelowi podejścia do kwestii, jakim jest dobrze uzasadniona nadzieja zbawienia takich dzieci. Od kiedy kard. Ratzinger określił limbus mianem „hipotezy teologicznej” ${ }^{15}$, Katechizm Kościoła katolickiego przekazał nowinę o „nadziei, że istnieje jakaś droga zbawienia" ${ }^{16}$ dla tych najmniejszych, a w deklaracji Dominus Iesus ogłoszono, że łaska Boża udzielana jest każdemu człowiekowi i posiada jednocześnie tajemniczy związek z Kościołem ${ }^{17}$, teoria limbus puerorum została praktycznie umieszczona $\mathrm{w}$ archiwum teorii teologicznych. Mimo to zdarzają się pojedyncze głosy twierdzące, że nauka o niewidzeniu Boga przez nieochrzczone dzieci jest ciągle żywa i nie można się z nią tak łatwo pożegnać ${ }^{18}$.

G. J. Dyer, Limbo. Unsettled question, New York 1964, s. 162-165; W. Granat, Sakramenty święte. Chrzest, bierzmowanie, pokuta, Lublin 1966, cz. 2, s. 124.

15 J. Ratzinger, V. Messori, Raport o stanie wiary, przekł. Z. Oryszyn, Marki 2005, s. 132-133.

16 KKK 1261.

${ }_{17}$ Zob. Kongregacja Nauki Wiary, Deklaracja o jedyności i powszechności zbawczej Jezusa Chrystusa i Kościoła Dominus Iesus 11;20-21, [w:] W trosce o pełnię wiary. Dokumenty Kongregacji Nauki Wiary 1995-2000, red. J. Królikowski, Z. Zimowski, Tarnów 2002, s. 82; 90-91.

18 Por. B. Cole, Is limbo still in limbo?, „Homiletic and Pastoral Review” 85 (1985), z. 6, s. $56-$ 64; tenże, Is limbo ready to be abolished? Limbo revisited, „Nova et Vetera” 6 (2008), z. 2, s. 417-418; B. Harrison, Could limbo be ,abolished”?, „Seattle Catholic” z 7.12.2005, [w:] http://www.seattlecatholic.com/a051207.html (01.06.2012); M. Hauke, Abschied vom Limbus?, „Theologisches” 37 (2007), 
W końcu ze względu na liczne pytania od biskupów i wiernych dotyczące rzeczywistego stanu tych dzieci, Jan Paweł II nakazał Międzynarodowej Komisji Teologicznej dogłębnie przebadać to skomplikowane zagadnienie. Po zebraniu danych z ośrodków naukowych i episkopatów na całym świecie Komisja przedstawiła wnioski w dokumencie Nadzieja zbawienia dla dzieci zmarlych bez chrztu wydanym w 2007 roku. Wyrażając szacunek dla dokonań teologicznych przeszłości, członkowie Komisji uznali otchłań dzieci za „teologicznie możliwą hipotezę”, która nigdy nie stała się definicją dogmatyczną ${ }^{19}$. Następnie przedstawili argumenty za nadzieją na zbawienie tych dzieci: miłosierna dobroczynność Boga, który swą łaską dotyka każdego człowieka; solidarność Chrystusa z całą ludzkością, dla której umarł, zmartwychwstał i przez ludzką naturę się z nią zjednoczył; więź z Kościołem i udział w obcowaniu świętych, dzięki modlitwie za zbawienie wszystkich i votum baptismi Ecclesiae; zasada lex orandi, lex credendi, wedle której modlitwa liturgiczna wyrażająca nadzieję na miłosierdzie Boże względem dziecka stanowi obraz i formę sensusfidei Kościoła. W podsumowaniu swoich badań Komisja stwierdziła:

\begin{abstract}
Nasze wnioski są takie, że wiele czynników, które rozpatrywaliśmy powyżej, daje poważne teologiczne i liturgiczne powody do tego, by mieć nadzieję, iż dzieci zmarłe bez chrztu będą zbawione i będą mogły cieszyć się wizją uszczęśliwiającą. Podkreślamy, że chodzi tu o powody nadziei w modlitwie, a nie o elementy pewności. [...] istnieją mocne powody ku temu, aby mieć nadzieję, że Bóg zbawi te dzieci, gdyż nie można było uczynić dla nich tego, czego by się pragnęło, czyli ochrzcić je w wierze i w życiu Kościoła ${ }^{20}$.
\end{abstract}

Droga od radykalnych przemyśleń Augustyna i Fulgencjusza do decyzji współczesnych teologów wchodzących w skład Międzynarodowej Komisji Teologicznej okazała się bardzo trudna, długa i wyboista. W związku z tym nasuwają się pytania: Dlaczego przejście od płomieni piekła do nadziei zbawienia zajęło Kościołowi aż kilkanaście wieków? Czy można w związku z tym powiedzieć, że Kościół błądził albo się mylił?

z. 7/8, s. 258-266; J. M. Schwarz, Die bleibende Frage nach dem Heil ungetauft sterbender Kinder, „Forum Katholische Theologie" 23 (2007), z. 4, s. 263; 283-284.

19 Międzynarodowa Komisja Teologiczna, Nadzieja zbawienia dla dzieci zmarlych bez chrztu. Uwagi wstępne, Radom 2008, s. 6 [dalej: MKT].

20 Tamże, 102-103. 


\section{Przyczyny powściągliwości Kościoła}

Na tempo procesu przemian w myśleniu o losie tych najmłodszych wpłynęły w dużej mierze zwłaszcza dwa czynniki: warunki historyczne oraz drobiazgowy i długotrwały proces dochodzenia do pełni rozumienia prawd wiary.

Ten pierwszy aspekt przejawiał się przede wszystkim w walce chrześcijańskich apologetów z różnorodnymi herezjami, które dotyczyły między innymi zaprzeczania konieczności chrzczenia małych dzieci i obecności w nich grzechu pierworodnego. Najwyraźniej widać to na przykładzie odmiennego podejścia do naszej kwestii ojców greckich i łacińskich w pierwszych wiekach chrześcijaństwa. Ci pierwsi, walcząc z pesymistyczną, fatalistyczną i dualistyczną nauką Manesa, podkreślali osobistą odpowiedzialność za grzech i karę za niego należną, a zatem w konsekwencji wyznaczyli nieochrzczonym dzieciom neutralny los pomiędzy chwałą nieba i ogniem piekła. Ojcowiełacińscy musieli zmagać się z przesadnym optymizmem pelagian przeczących istnieniu winy pierworodnej w niemowlętach, co doprowadziło do absolutnego przestrzegania zasady, że jedynym środkiem zbawienia dla nich jest chrzest przyjęty in re. Podobne polemiki Kościół i teologowie musieli prowadzić z katarami, a potem anabaptystami. W tamtych czasach nie do pomyślenia była sytuacja, w której ktoś mógłby osiągnąć zbawienie, nie przynależąc do Kościoła przez święty chrzest. Oznaczałoby to po pierwsze, że sakrament odrodzenia w Chrystusie i Kościół jako wspólnota zbawienia są niepotrzebne, po drugie znaczenie grzechu pierworodnego zostałoby zminimalizowane i w związku z tym ofiara Syna Bożego uległaby dewaluacji, a po trzecie stanowiłoby to po części przyznanie racji heretykom.

Wiąże się to bardzo ściśle z ekskluzywistycznym rozumieniem zasady extra Ecclesia nulla salus, głoszonym głównie przez szkołę Augustyna, a zwłaszcza przez Fulgencjusza z Ruspe ${ }^{21}$, który wyrzucał poza nawias zbawienia wszystkich ludzi nienależących w widzialny sposób do Kościoła. Ta zdeformowana teza wynikła z przedawnionego poglądu na świat, wedle

${ }^{21}$ Por. Fulgencjusz z Ruspe, 0 wierze, czyli o regule prawdziwej do Piotra XXXVII 79, [w:] A. Bober, Studia i teksty patrystyczne, Kraków 1967, s. 242: „Jak najmocniej się tego trzymaj i bynajmniej nie wątp, iż nie tylko wszyscy poganie, lecz również wszyscy Żydzi, wszyscy heretycy i schizmatycy, którzy poza Kościołem katolickim teraźniejsze kończą życie, pójdą w ogień wieczny, zgotowany szatanowi i aniołom jego". 
którego cały świat był chrześcijański i kto nie należał do Kościoła, był uważany za samemu sobie winnego tego faktu. Jednakże wziąwszy pod uwage prawdę, że duża część ludzkości to poganie żyjący na nowo odkrytych kontynentach, oficjalne nauczanie Kościoła podkreśliło, że Chrystus umarł za wszystkich ludzi, a Jego łaska może być udzielana także poza widzialnymi granicami Kościoła ${ }^{22}$. Zbawienie dokonuje się bowiem wyłącznie przez Chrystusa, a tam, gdzie jest Chrystus, znajduje się teżJego Kościół realizujący tę samą misję zbawczą wobec wszystkich ludzi, także tych, którzy nie mogli dojść do wiary i poznania prawdy ${ }^{23}$. Jeśli zatem Chrystus przez Ducha Świętego w sobie tylko znany sposób udziela zbawienia zmarłym bez sakramentu odrodzenia dzieciom, oznacza to iż owo zbawienie jest eklezjalne ze swej natury, czyli ma tajemniczy związek z Kościołem ${ }^{24}$.

Takie odejście od automatycznego sakramentalizmu i zbawczego rygoryzmu było możliwe dzięki dochodzeniu do pełniejszej świadomości niektórych prawd poprzez plan Bożej pedagogii. Fundamentalne dla naszej kwestii prawdy, od których nie może ona być oderwana, takie jak powszechna wola zbawcza Boga, solidarność Chrystusa z całą ludzkością, miłosierna miłość Stwórcy, konieczność chrztu i Kościoła do zbawienia, istnienie i skutki grzechu pierworodnego, dzięki rozwojowi historii rozumienia wiary, o jakim mówi soborowa konstytucja Dei Verbum, zyskały nową perspektywę i właściwą ocenę. Kościół bowiem z biegiem wieków dąży stale do pełni prawdy Bożej, dzięki refleksji i badaniom wierzących, doświadczeniu rzeczy duchowych i przepowiadaniu Magisterium (zob. KO 8).

Kiedy więc w dziejach chrześcijańskiej refleksji zaczęto zadawać sobie pytanie o los dzieci zmarłych bez chrztu, nie znano dokładnie ani natury tej kwestii, ani wszystkich aspektów i całego doktrynalnego znaczenia w niej zawartego. Duch Święty nieustannie oświeca swój Kościół, dając lepsze rozumienie spraw Bożych w konkretnych warunkach historycznych. Wymiary i złożo-

22 Zob. Innocenty X, Constitutio „Cum occasione” 5, DS 2005; Klemens XI, Constitutio „Unigenitus Dei Filius” 29, DS 2429; Pius IX, Allocutio „Singulari quadam”, [w:] tegoż, Epistola encyclica [„Quanta cura"] ... unacum Syllabo Praecipuorum aetatis nostrae errorum et actis pontificis ex quibus excerptus est Syllabus, Ratisbonae 1865, s. 80; Sacrum Officium, Epistola ad archiepiscopum Bostoniensem, DS 38663873; KK 13-16; KDK 22; J. Ratzinger, Salus extra Ecclesiam nulla est, „Znak” 131 (5) 1965, s. 611-618.

${ }_{23}$ Por. Kongregacja Nauki Wiary, Deklaracja o jedyności i powszechności zbawczej Jezusa Chrystusa i Kościoła Dominus Iesus 11; 20-21.

24 Por. Jan Paweł II, Encyklika Redemptoris missio 10; MKT 96-99. 
ność prawdy o losie nieochrzczonych dzieci nie były kiedyś znane, ujawniły się dopiero w historycznym i teologicznym rozwoju w ciągu wieków, co pozwoliło na jej właściwą ocenę oraz postęp tej nauki wskutek pogłębionych studiów ${ }^{25}$. Prawda ta dojrzewała dosyć długo, nim można ją było odczytać w pełnym bogactwie aspektów, a przez to w odpowiednim kontekście. Dzięki osiągnięciom Soboru Watykańskiego II zdano sobie sprawę, że to szczegółowe zagadnienie zasługiwało na uwzględnienie go w szerszym zakresie doktryny wiary i przemyślenie go na nowo, dzięki umieszczeniu w całościowym kontekście wiary katolickiej i uwzględnieniu zasady hierarchii prawd, o której mówi soborowy dekret Unitatis redintegratio (zob. DE 11).

To, że nasza kwestia dopiero w XX wieku zyskała odpowiednie światło i ujawniła swój prawdziwy splendor, wynika zatem z wielu czynników ograniczających, które Kościół, dzięki pomocy Ducha Świętego, zdołał w końcu przezwyciężyć. Nie oznacza to, że wszystkie wnioski w ciągu dziejów tego pytania należy uznać za błędne i nieprawdziwe. Rozwiązania przedstawione przez ojców Kościoła, doktorów scholastycznych i innych teologów, nawet te radykalne i surowe, mimo wszystko w sposób nieunikniony wpisują się w rozwój właściwego postrzegania losu nieochrzczonych dzieci. Dzisiejsze osiągnięcia nie byłyby możliwe bez kilkunastu wieków (niekiedy wychodzących poza sztywne ramy myślenia swych epok) teologicznych dyskusji i polemik, jakie przyczyniły się do stopniowego dochodzenia do pełni prawdy. Nie oznacza to również, że los tych najmniejszych zmieniał się z biegiem lat równolegle do tworzenia przez myślicieli nowych teorii na ten temat. Pozostał taki sam bez względu na to, czy były to czasy Augustyna, Tomasza z Akwinu, czy epoka współczesna. Jedynym elementem, którym uległ zmianie, jest ludzkie myślenie, które Boża opatrzność doprowadziła w końcu do właściwych, nieograniczonych czynnikami zewnętrznymi wniosków.

Podsumowując, można odejść od przerażającej wizji piekła czy otchłani i mieć nadzieję na Boże miłosierdzie względem tych najmniejszych zmarłych bez chrztu dzięki temu, że: grzech pierworodny przestał być postrzegany jako mroczna, od początku nieuchronnie determinująca los człowieka rzeczywistość, niemożliwa do usunięcia przez środek inny niż chrzest

25 Por. MKT, Uwagi wstępne; Kongregacja Nauki Wiary, Instrukcja o powołaniu teologa w Kościele Donum veritatis 24, [w:] W trosce o petnię wiary. Dokumenty Kongregacji Nauki Wiary 19661994, red. J. Królikowski, Z. Zimowski, Tarnów 1995, s. 361-362. 
in re, ze względu na nieskończone Boże miłosierdzie, które opromienia każde ludzkie istnienie od momentu jego poczęcia; powszechna Boża wola zbawienia wszystkich ludzi nie jest ograniczona tylko do tych, którzy mieli możliwość dojścia do wiary i przyjęcia chrztu, dlatego zajmuje pozycję nadrzędną względem prawdy o konieczności do zbawienia sakramentu odrodzenia przyjętego in re; natomiast nieskończone miłosierdzie Boże wobec każdego człowieka, zwłaszcza tego najbardziej bezbronnego i potrzebującego pomocy, pozwala mieć mocną nadzieję, że nie pozostawi go bez szansy na zbawienie, ponieważ taka fatalistyczna myśl nie może być w żaden sposób przypisana Bogu Objawienia.

Patrząc wstecz na obawy starożytnych dotyczące ewentualnych zagrożeń takiego myślenia dla depozytu wiary, można powiedzieć, iż grzech pierworodny nie został w żadnej mierze zdewaluowany, a zbawcza moc Chrystusa nie została zdegradowana. Ów grzech nadal stanowi niebezpieczeństwo dla szczęścia wiecznego - został jedynie zrzucony z piedestału, na którym stawiali go niektórzy teologowie, nie doceniając wszechmocy i pierwszeństwa Boga w dziele odkupienia każdego człowieka. Z kolei zbawcza potęga Chrystusa w żadnym wypadku nie została pomniejszona, lecz jeszcze lepiej uwypuklona i postawiona na pierwszym miejscu, „zrzucając łańcuchy" ograniczeń takich jak negatywne konsekwencje podziału na wolę zbawczą uprzednią (voluntas antecedens) i następczą (voluntas consequens) ${ }^{26}$.

\section{B. Wymiar egzystencjalny kwestii}

$\mathrm{Z}$ racji tego, że określone postępowanie stanowi najczęściej wynik konkretnego modelu myślenia, można stwierdzić, że różne zachowa-

26 Jednym z wielu przykładów skutków takiego myślenia mogą być poglądy Gabriela Vásqueza w Commentariorum ac disputationum in Primam Partem S. Thomae, d. 96, cap. 2-3, Ingolstadii 1609, t. 1, s. 715-716. Ogólnie mówiąc, chodzi o podział Bożej woli zbawienia wszystkich ludzi na uprzednią (Bóg chce, by każdy człowiek był zbawiony) oraz następczą (aby ta Boża wola w człowieku przyniosła efekt, musi on spełnić pewne warunki, z których na pierwszym miejscu jest przyjęcie chrztu z wody). Rozwój takiej perspektywy patrzenia na wolę zbawczą Boga doprowadził gdzieniegdzie do ograniczenia jej powszechności i wykluczenia niektórych ludzi nawet z możliwości dostępu do łaski odkupienia. Przyczynił się także do stworzenia negatywnego wizerunku Boga, postrzeganego jako Ten, który nie musi przejmować się tymi, którym nie dane było zaznać odradzającego obmycia chrzcielnego. 
nia duchownych i świeckich, jeśli chodzi o praktyczną stronę naszej kwestii, były i są konsekwencją obowiązującej w danym czasie teologii. Sposób myślenia katolickich teologów miał i nadal ma niezwykle doniosłe znaczenie dla praktyki wiary, a niekiedy nawet wpływa na zachowania pseudoreligijne.

\section{Krótki zarys historyczny}

Źródła wiedzy dotyczące wpływu radykalnej teologii Augustyna i jego szkoły na zachowania chrześcijan w pierwszych dziesięciu wiekach są nad wyraz skąpe. Bardziej szczegółowe dane pojawiają się dopiero w scholastycznym okresie średniowiecza i odnoszą się do sposobów udzielania chrztu dzieciom, których życie było zagrożone, bądź sposobów sprawowania pochówku najmłodszych, którym chrzest z różnych przyczyn nie został udzielony. Jeśli chodzi o okres obejmujący pierwsze dwanaście wieków chrześcijaństwa, można się oprzeć jedynie na pojedynczych źródłach i domysłach. Skoro bowiem nieochrzczone dzieci miały płonąć w ogniu piekła, to miejscem spoczynku ich ciał nie mogła być poświęcona ziemia cmentarza, natomiast nieustanne apele duszpasterzy, by ochrzcić swą pociechę w kościele jak najszybciej, zmuszały niekiedy zaniepokojonych mroczną wizją przyszłości rodziców do zachowań ekstremalnych ${ }^{27}$.

Często śmierć nieochrzczonego potomka wiązała się nie tyle z rozpaczą i żałobą jego bliskich, ile z irracjonalnym i zabobonnym strachem przed małym nieboszczykiem. Jeden z przejawów takich lęków opisał Burchard z Wormacji w XI wieku, relacjonując zwyczaje obowiązujące w krajach, które wychodziły dopiero z pogaństwa. Ciała małych dzieci, które za życia nie zaznały obmycia odradzającego, przebijane były kołkiem i przytwierdzane do podłoża, by nie mogły powrócić jako upiory i zaszkodzić żyjącym ${ }^{28}$. Taki barbarzyński ryt to konsekwencja nie tylko mentalności

27 Por. J. Kracik, Śmiertelne skutki pewnej teologii. O losach dziecizmarłych bez chrztu, [w:] Poronienie. Zrozumieć rodziców po stracie, red. C. Klahs, Poznań 2010, s. 161-163.

28 Por. D. Lett, De l'errance au deuil. Les enfants morts sans baptême et la naissance du limbus puerorum aux XIIe-XIIIe siècles, [w:] La petite enfance dans l'Europe médievale et moderne, wyd. R. Fossier, Toulouse 1997, s. 87; I. Séguy, M. Signoli, Quand la naissance côtoie la mort: pratiques funéraires et religion populaire en France au moyen Age et à l'époque moderne, [w:] Nasciturus: infans, puerulus, vobis mater terra, wyd. F. Gusi, S. Muriel, C. Olària, Castellon 2008, s. 505. 
pogańskiej i myślenia magicznego, ale również nauki o piekielnym przeznaczeniu nieochrzczonych.

W czasie kiedy posłuch na uniwersytetach zyskała teoria o braku cierpień w otchłani, w literaturze i sztuce tamtego kresu daje się zauważyć pewne złagodzenie radykalnej wizji zaświatów. Popularny wśród kleru podręcznik katechetyczny autorstwa Honoriusza z Autun roztaczał przed wiernymi perspektywę istnienia nieochrzczonych dzieci w miejscu mrocznym, gdzie nie ma nadziei na spotkanie ze Stwórcą ${ }^{29}$. Autor Boskiej komedii Dante Alighieri wyobrażał sobie otchłań jako pierwszy, najbardziej zewnętrzny krąg piekła, w którym dzieci i inni nieochrzczeni cierpieli nieznośną tęsknotę za niedosięgłym niebem ${ }^{30}$. Z kolei na obrazie Koronacja Marii francuskiego malarza Enguerranda Quartona z połowy XV wieku można zauważyć zaświaty, których jedna z części stanowi otchłań dzieci. Posiada ona formę szczelnie zamkniętej jaskini, gdzie panuje ciemność, a jej mieszkańcy, przedstawieni jako oranci, adorują Trójcę Świętą z zamkniętymi oczyma, co oznacza, że nie zaznali światła chrztu świętego ${ }^{31}$.

Jednak dla dużej większości wiernych, którzy opierali się przede wszystkim na naukach usłyszanych z ambony bądź nie do końca potwierdzonych własnych wyobrażeniach, zmiana z potępienia w ognistym piekle na potępienie w ciemnościach braku obecności Boga nie robiła żadnej różnicy. Pragnienie zapewnienia zbawienia swemu często jeszcze nienarodzonemu dziecku oraz żal i strach po jego utracie w stanie grzechu pierworodnego, który mógł odpuścić jedynie chrzest z wody, przyczyniły się do wielu niepokojących zjawisk oraz zabobonnych zachowań, niezgodnych z chrześcijańskim duchem pobożności.

Wśród wielu udokumentowanych przykładów można wymienić między innymi pseudochrzty dokonywane na brzuchu kobiety brzemiennej, próby dokonywania chrztu post mortem czy rozwój średniowiecznych mirakulów, które obejmowały cudowne wskrzeszenia dzięki wstawiennictwu

29 Por. Honoriusz z Autun, Elucidarium sive Dialogus de summa totius Christianae theologiae III 4-6, PL 172, kol. 1159-1161; II 15, PL 172, kol. 1146: „Quam poenam habent parvuli sine baptismo mortui? Tenebras tantum".

30 Por. D. Alighieri, Piekło: Boskiej komedii część pierwsza, pieśń 4, 1-63, przeł. A. Kuciak, Poznań 2002, s. 33-35.

31 Por. D. Lett, De l'errance au deuil..., dz. cyt., s. 91-92. 
i interwencji świętych, by można było przywróconemu do życia maleństwu udzielić sakramentu ${ }^{32}$.

Ścisły związek z tą ostatnią grupą zjawisk ma rozwój w Europie Zachodniej w wiekach XIV-XIX tak zwanych „sanktuariów odroczenia” (sanctuaires à repit), gdzie przynoszono martwe ciałka dzieci w nadziei, że dzięki gorliwej modlitwie Bóg przywróci je do życia, by można je było wyrwać z ciemności przez sakrament odrodzenia, a po powrocie do śmiertelnego stanu pochować w poświęconej ziemi cmentarza. Wiedzeni tą nadzieją rodzice przynosili swe zmarłe pociechy przed ołtarz, najczęściej z figurą Matki Bożej, i błagali o jakiekolwiek znaki życia. Jeśli uznano, że takowe nastąpiły, udzielano chrztu warunkowo i chowano na przyległym do sanktuarium specjalnie dla nich przeznaczonym cmentarzu. Takie praktyki doprowadziły do częstych nadużyć i w konsekwencji do „udzielania chrztu” martwym dzieciom, bowiem za oznaki życia uchodziły: ruch członków ciała, zmiana koloru czy ciepłoty ciała, pojawienie się łez lub potu czy stwierdzenie oddechu. Na podstawie tych przesłanek nie da się jednoznacznie stwierdzić, że dziecko ożyło, zważywszy na fakt, że opierały się one wyłącznie na świadectwach prostych ludzi, którzy zwykle rezydowali przy takich świątyniach. W związku z tym władze kościelne często zabraniały tych praktyk, lecz bezskutecznie. W końcu po interwencji Świętego Oficjum, które w 1729 roku wydało dekret potępiający je, określono, że za oznaki życia należy uznać płacz i kwilenie, a wspomniane wcześniej „dowody” i świadectwa są niewystarczające. Dlatego chrztu należy udzielać tylko i wyłącznie po ewidentnym stwierdzeniu tych dwóch objawów życia ${ }^{33}$. Ów dekret był powtarza-

32 Por. J. Gélis, Les enfants des limbes. Morts-nés et parents dans l'Europe chrétienne, Paris 2006, s. 309-314; J. Kracik, Śmiertelne skutki pewnej teologii..., dz. cyt., s. 160; R. C. Finucane, The rescue of the innocents. Endangered children in medieval miracles, New York 2000, s. 42-43.

33 Por. J. Gélis, L'arbre et le fruit. La naissance dans l'Occident moderne. XVIe-XIXe siècle, Paris 1984, s. 509-520; Les enfants des limbes. Morts-nés et parents dans l'Europe chrétienne..., dz. cyt., s. 121; 267; Lebenszeichen-Todeszeichen: Die Wundertaufe totgeborener Kinder im Deutschland der Aufklärung, [w:] Rituale der Geburt. Eine Kulturgeschichte, red. J. Schlumbohm, Munich 1998, s. 269288; D. Lett, L'enfant des miracles: enfance et société au Moyen Age (XIIe-XIIIe siècle), Paris 1997, s. 207; I. Séguy, M. Signoli, Quand la naissance côtoie la mort..., dz. cyt., s. 502; M. F. Morel, La mort d'un bébé au fil de l'histoire, „Spirale” 31 (2004), z. 3, s. 23; J. Kracik, Chrzest w staropolskiej kulturze duchowej, „Nasza Przeszłość” 74 (1990), s. 198; E. Pahud de Mortanges, Der versperrte Himmel. Das Phänomen der „,sanctuaires à répit” aus theologiegeschichtlicher Perspektive, „Schweizerische Zeitschrift für Religionsund Kulturgeschichte" 98 (2004), s. 39-41; A. Natalis (A. Noël), Theologia dogmatica et moralis, lib. 2, 
ny jeszcze sześciokrotnie, co wskazuje na wielkie przywiązanie wiernych do takich rytów oraz problemy hierarchów z ich usunięciem.

Nadużycia związane z próbami chrzczenia bardzo małych dzieci, nawet tych nienarodzonych, miały również miejsce na płaszczyźnie medycznej. Bezwzględne rozumienie prawdy o konieczności chrztu z wody do zbawienia doprowadziło w niektórych przypadkach do nadmiernego rytualizmu, przejawiającego się udzielaniem sakramentu odrodzenia in utero za pomocą rurki lub strzykawki w razie zagrożenia życia dziecka lub matki. Pozytywnym aspektem tych zachowań było zwrócenie uwagi na prawdę, że można chrzcić także ludzkie embriony i płody, które uległy poronieniu ${ }^{34}$.

Innym przejawem wymiaru egzystencjalnego kwestii losu wiecznego nieochrzczonych dzieci są praktyki związane z ich pochówkiem. Jako niechrześcijanie nie miały prawa być pochowane na poświęconej części cmentarza, dlatego najczęściej wyznaczano w jego pobliżu teren nieuświęcony błogosławieństwem, gdzie składano ich szczątki tuż obok niewierzących, odstępców, heretyków, ekskomunikowanych, samobójców i publicznych grzeszników. Niekiedy rodziny tych dzieci nie mogły się pogodzić z tak jawnym wykluczeniem poza krąg nadziei na zbawienie i dokonywały potajemnego pogrzebu na poświęconej części nekropolii. Inni, chcąc zapewnić swym potomkom chociaż pośmiertną bliskość sacrum, chowali ich pod murami kościołów, pod ich rynnami i przy baptysteriach, by spływała na nich woda z miejsc świętych. Taki rodzaj myślenia magicznego był dosyć częsty w średniowieczu, czego dowodzą wykopaliska archeologiczne prowadzone wokół współczesnych i dawnych miejsc kultu. Tego typu zachowania były wyrazem ufności w to, że na dzieci, które nie mogły być ochrzczone za życia, spłyną po śmierci jakieś łaski analogiczne do chrztu i wywrą na nie zbawienny wpływ ${ }^{35}$.

tract. 2, cap. 7, reg. 3, Parisiis 1767, s. 457-458; Benedykt XIV, De synodo dioecesana, lib. 7, cap. 6, nr 11-12, [w:] tegoż, Opera omnia, Prati 1844, vol. 11, s. 204-205.

34 Por. F. E. Cangiamila, Embriologia sacra, lib. 1, cap. 3, nr 2; lib. 3, cap. 5, nr 14, Milano 1751, s. 16; 215-216; A. Katolo, Moralny obowiazek pomocy dziecku nienarodzonemu, Lublin 2006, s. 87; 147148; I. M. Riesco Le-Grand, Tratado de Embriologia Sagrada, parte 2, cap. 4, par. 5, Madrid 1848, s. $314-323$.

35 Por. J. Kracik, Chrzest w staropolskiej kulturze duchowej..., dz. cyt., s. 198; M. F. Morel, La mort d'un bébé au fil de l'histoire..., dz. cyt., s. 22; R. C. Finucane, The rescue of the innocents..., dz. cyt., s. 4546; P. Martin, Les répits en Lorraine, „Mémoires de l'Académie de Stanislas” 18 (2003-2004), s. 532; P. Duma, Grób alienata. Pochówki dzieci nieochrzczonych, samobójców i skazańców w późnym średniowie- 
Nie zawsze jednak szczątki doczesne nieochrzczonych dzieci grzebano przy świątyniach czy kaplicach. Dane archeologiczne wskazują na to, iż takie groby znajdowano przy klasztornych i kościelnych ogrodzeniach, w ogrodach, w polu, pod figurą czy krzyżem, pod drzewem, na dziedzińcu domu czy pod progiem. Część rodzin, kierując się ówczesną mentalnością, wedle której fizyczny los dziecka jest nieistotny, skoro nie można go pochować jak chrześcijanina, wrzucała jego ciało do zsypów na śmieci, latryn bądź pozostawiała na pożarcie domowym zwierzętom. Władze kościelne nakazywały zatem, by ze względu na godność chrzcielną rodziców chowali oni swe nieobmyte wodami chrztu dzieci na niepoświęconej, specjalnie dla nich przeznaczonej części cmentarza ${ }^{36}$. Zawsze istniało również niebezpieczeństwo, że zwłoki nieochrzczonych dzieci mogą zostać wykorzystane w okultyzmie, do zabobonnych praktyk, tworzenia amuletów, czarnej magii i czarów. Czasami rodzice musieli ukrywać miejsce pochówku swego dziecka, by uniknąć zbezczeszczenia jego ciała ${ }^{37}$.

Wokół grobów, zwłok i dusz takich dzieci krążyły także legendy oraz towarzyszyła im aura tajemniczości i lęku. W opowieściach ludowych często spotyka się opisy zjaw dzieci pojawiających się pod różnymi postaciami na skrajach lasów, nad brzegami zbiorników wodnych czy na rozwidleniach dróg, proszących przechodniów o chrzest i nadanie imienia ${ }^{38}$.

Jeśli chodzi o teologiczną ocenę takich opowieści, można powiedzieć, iż jest to wyraźny przejaw przekonania ówczesnych wiernych o nieszczęśliwym losie takich dzieci w zaświatach, gdzie nie istnieje ani wieczny spokój, ani szczęście i zbawienie. Jest to też przejaw pseudoreligijnego myślenia, które uparcie szuka rozwiązań i szans na zbawienie tam, gdzie tak naprawdę ich nie ma. To także konsekwencja milczenia Kościoła jeśli chodzi o oficjalne i definitywne nauczanie w kwestii losu tych najmniejszych.

czu i dobie wczesnonowożytnej, Kraków 2010, s. 17-25; 43-49; 57; I. Séguy, M. Signoli, Quand la naissance côtoie la mort..., dz. cyt., s. 505-506.

36 Warto zobaczyć decyzje niektórych synodów lokalnych, np. z XVIII i XIX wieku: Collectio Lacensis I 513; III 505; IV 1006; V 91; 190; 868; VI 31.

37 Por. P. Martin, Les répits en Lorraine..., dz. cyt., s. 532; P. Duma, Grób alienata..., dz. cyt., s. 28 31; I. Séguy, M. Signoli, Quand la naissance côtoie la mort..., dz. cyt., s. 506.

38 Por. A. O'Connor, The blessed and the damned. Sinful women and unbaptised children in Irish folklore, Bern 2005, s. 65-124; J. Kracik, Chrzest w staropolskiej kulturze duchowej..., dz. cyt., s. 200; P. Duma, Grób alienata..., dz. cyt., s. 18-19; D. Lett, De l'errance au deuil..., dz. cyt., s. 86-87; M. F. Morel, La mort d'un bébé au fil de l'histoire..., dz. cyt., s. 22; P. Martin, Les répits en Lorraine..., dz. cyt., s. 532. 
Dopiero wtedy, kiedy zdano sobie sprawę z szerokiego wachlarza aspektów i całej dogmatycznej doniosłości tego pytania, oprócz przeobrażeń czysto teoretycznych możliwe były konkretne zmiany na płaszczyźnie chrześcijańskiej praxis.

\section{Współczesna praktyka Kościoła}

W okresie posoborowym dokonało się najwięcej zmian, jeśli chodzi o teksty liturgiczne i prawo kanoniczne. Nowy Kodeks Prawa Kanonicznego z 1983 roku usunął zapis obecny jeszcze w starym Kodeksie z 1917 roku o osobach zmarłych bez chrztu jako tych, którym należy odmówić pogrzebu kościelnego i pochówku w poświęconej ziemi ${ }^{39}$. Zamiast tego czytamy: „Ordynariusz miejsca może zezwolić na pogrzeb kościelny dzieci, których rodzice mieli zamiar je ochrzcić, a jednak zmarły przed chrztem"40. Konferencja Episkopatu Polski pozwoliła, aby na terenie diecezji polskich można było odprawić ten obrzęd bez każdorazowej prośby do biskupa o pozwolenie. Po reformie liturgicznej opartej o wskazania soborowej konstytucji Sacrosanctum Concilium Mszał Rzymski z 1970 roku dysponuje mszą pogrzebową dla nieochrzczonych dzieci, a w Ordo exequiarum pojawiły się nowe modlitwy. Sam obrzęd pogrzebowy zawiera wiele elementów zachęcających do nadziei i ufności w Boże miłosierdzie nad tymi najmniejszymi. Agendy liturgiczne i zbiory błogosławieństw wzbogaciły się o modlitwy za dzieci nienarodzone oraz prośby, by te maleństwa, które umarły przed chrztem, mogły spotkać się ze swymi matkami w królestwie niebieskim ${ }^{41}$.

Ewolucja w patrzeniu na los tych dzieci zamanifestowała się nie tylko w traktatach teologicznych, katolickich podręcznikach i encyklopediach czy przepisach prawnych i liturgicznych. Stała się też jedną z przyczyn in-

\footnotetext{
39 Zob. CIC 1239, §1.

$40 \quad$ KPK 1183, §2; 1184.

41 Por. Obrzędy pogrzebu dostosowane do zwyczajów diecezji polskich, nr 22, 144B, 145B, 150, 251254, 358-361, Katowice 1995, s. 20; 139-140; 144; 220-221; 299-301; Agenda liturgiczna diecezji opolskiej. Nabożeństwa, poświęcenia i błogosławieństwa, Opole 1981, s. 521-524; Collectio rituum. Continens excerpta e Rituali Romano. Ecclesiis Poloniae adaptato, tit. 7, cap. 4; 6, Katowice 1963, s. 182-188; $194-$ 195; 197-198; Obrzędy błogosławieństw dostosowane do diecezji polskich, nr 156-173, Katowice 1994,
} t. 1 , s. $77-84$. 
nego spojrzenia na człowieczeństwo i godność najmniejszych przedstawicieli rodzaju ludzkiego. Zmieniło się podejście teologów, duchownych, lekarzy i wszystkich, którym leży na sercu ta kwestia. Duszpasterze odchodzą od tak zwanych „pokropków”, czyli zwykłego pokropienia trumny wodą święconą z towarzyszeniem modlitwy i odprawiają mszę świętą w intencji rodziny, by złożyła swą nadzieję w miłości Bożej, która nikogo nie wyklucza. Lekarze w szpitalach zobowiązani są do wydawania ciał dzieci poronionych rodzicom, którzy chcą je pochować bez względu na stopień rozwoju fizycznego. Natomiast coraz powszechniejszą praktyką stają się zbiorowe pogrzeby szczątków dzieci, po których ciała nikt się nie zgłosił do placówki medycznej. Także przepisy kościelne uwypuklają potrzebę szacunku dla ludzkiego ciała, nawet tak małego, którego nie wolno traktować jak odpadów czy używać do celów handlowych i produkcyjnych. Taki stosunek chrześcijan do ciał nieochrzczonych dzieci stanowi widoczny znak i świadectwo dla świata o wielkiej godności życia ludzkiego stworzonego przez Boga ku nieśmiertelności oraz jest potwierdzeniem w praktyce nauki Kościoła o obronie życia nienarodzonych. Skoro bowiem walczy o prawo do życia i szacunek dla nich jako ludzi, to czy skaże ich doczesne szczątki na zapomnienie wśród medycznych odpadów bądź rzuci na pastwę przemysłu kosmetycznego? Podobnie pogrzeb na cmentarzu wśród wiernych jest widocznym znakiem pozostawania w obrębie nadziei na życie wieczne i zmartwychwstanie ciał w Dniu Ostatecznym.

Mimo że kwestia teologiczna losu tych najmniejszych osiągnęła wysoki poziom rozwoju, a jej konsekwencje w codziennym życiu w znacznym stopniu wyzbyły się negatywnych objawów, nie można powiedzieć, że współcześnie nie rodzą się kolejne pytania, a wszystkie problemy zostały definitywnie rozwiązane. Ciągle nie wszędzie duszpasterze podchodzą do targanych rozpaczą rodziców z należytym szacunkiem i empatią, jeśli chodzi o organizację pogrzebu. Zdarzają się również przypadki zupełnie innej natury, kiedy podczas obrzędu pochówku czy w czasie mszy świętej pogrzebowej celebrans zalicza zmarłe dziecko do grona świętych, pomijając całkowicie rzeczywistość grzechu pierworodnego i zależność jego losu od Bożego miłosierdzia ${ }^{42}$, dając tym samym rodzicom pewność, której nie

42 Por. R. Martin, Believing and praying, „Homiletic and Pastoral Review” 104 (2003), z. 3, s. 64-66. 
mogą mieć. Jedynie Bóg jest tym, który daje zbawienie, a wiedzy o tym, co się dzieje z dzieckiem w chwili śmierci i po niej, nie zechciał nam przekazać. Należy zatem wypośrodkować stanowisko duszpasterskie, kładąc przede wszystkim nacisk na wielką nadzieję na miłosierdzie Boże i przez to na zbawienie w ramionach wszechmocnego Ojca, który tylko sobie znanymi drogami dociera do każdego człowieka. Nie może być mowy o ekstremach, takich jak wykluczenie bądź pochopna „kanonizacja”. To pierwsze byłoby powrotem do ograniczonych teorii przeszłości, zaś to drugie stwarza niebezpieczeństwo zlekceważenia konieczności chrztu dzieci jako jedynej powszechnej możliwości usunięcia grzechu pierworodnego, odejścia od modlitwy wstawienniczej za wszystkie tego rodzaju dzieci oraz zakwestionowania suwerenności Boga w podejmowaniu decyzji ${ }^{43}$.

To niezwykle trudne zadanie, bowiem rodzicom, którzy przychodzą do kapłana, by pochować swe nieochrzczone dziecko, żadne wytłumaczenie może nie wydawać się odpowiednie i wystarczające. Duszpasterz musi zatem wykazać się znajomością nie tyle teologii, ile przede wszystkim psychologii, a nawet retoryki.

Kolejnym problemem jest też ciężki wybór pomiędzy decyzją o ochrzczeniu dziecka, którego rodzice przypuszczalnie nie wychowają na chrześcijanina i nie zapewnią rozwoju jego wiary, a decyzją o odłożeniu chrztu, która wiąże się z ryzykiem przedwczesnej śmierci bez tego sakramentu. Rozwiązaniem mogą być rodzice chrzestni, którzy będą wpływać na rozwój duchowy dziecka, chociaż na pewno byłby to wpływ dosyć ograniczony. Innym wyjściem jest prawda o tym, że w niebezpieczeństwie śmierci chrztu dziecku może udzielić każdy człowiek z odpowiednią intencją. Jednakże nie wszyscy w takim momencie myślą o chrzczeniu umierającego, a czasami po prostu nie ma takiej możliwości.

Duży kłopot stanowi współcześnie, tak jak i niegdyś, myślenie magiczne, jeśli chodzi o sprawowanie sakramentów, w tym przypadku chrztu świętego, oraz zwykłe zabobony mające zapewnić „nieszczęsnym” dzieciom coś na kształt obmycia chrzcielnego. To drugie zagadnienie charakteryzuje o. Jacek Salij, pisząc o „chrzczeniu” dzieci po śmierci lub na odległość

${ }_{43}$ Por. L. Scheffczyk, Zur Frage des Heils der ungetauft verstorbenen Kinder, [w:] Leben angesichts des Todes: Referate der „Internationalen Theologischen Sommerakademie 2002” des Linzer Pristerkreises in Aigen, red. F. Breid, Buttenwiesen 2002, s. 78-81. 
poprzez kropienie wodą święconą na cztery strony świata, by „uratować” najmniejszych, którzy zmarli bądź zginą w wyniku aborcji ${ }^{44}$. Innymi zachowaniami pseudoreligijnymi jest na przykład traktowanie chrztu jak rytuału pełniącego funkcję automatycznie oczyszczającą z grzechu pierworodnego i zabezpieczającą przed ogólnie pojętym złem, diabłem czy niedobrymi ludźmi. Woda chrzcielna i słowa w tym wypadku traktowane sąjak posiadające moc same z siebie amulety, stanowiące niewidzialną barierę przed złymi urokami czy nieszczęśliwym życiem. Istnieje również wiele przesądów związanych z uroczystością udzielenia sakramentu odrodzenia - przykładowo wiąże się niemowlętom na przegubach rąk czerwone wstążki, mające zapewnić szczęście, zaś przed chrztem zabronione jest wychodzenie z dziećmi z domu.

Chrzest rzeczywiście powoduje odpuszczenie grzechów i wyzwolenie spod władzy Szatana, ale dzięki łasce Chrystusa, którą związał z tym sakramentem, a nie dzięki widocznym elementom jak woda czy słowa, które same w sobie bez łaski nic nie znaczą. Chęć chronienia dziecka od nieszczęść i tajemnicze obmycie z grzechu pierworodnego jako jedyna motywacja chrztu jest myśleniem magicznym, czyli chęcią użycia rytuałów kościelnych do własnych celów oraz wyrazem pragnienia władzy nad pewnymi tajemniczymi siłami, które uchronią dziecko automatycznie od wszelkiego zła. Nie ma tam mowy ani o nowym stworzeniu i łasce, ani o włączeniu w ciało Chrystusa i więzi z innymi ochrzczonymi, ani o charakterze chrzcielnym, ani o miłości, którą Chrystus ofiarowuje dziecku. Jest to tylko czysto formalny rytuał, w którym elementy widzialne pełnią rolę odstraszającą dla wszystkich życiowych porażek i mrocznych wpływów niewiadomego pochodzenia. Sakrament nie jest magią, lecz widocznym znakiem łaski Chrystusa - to On działa i tylko On ją nam ofiaruje.

Wypada również wspomnieć o innym nadużyciu, jakim jest przyjmowanie chrztu za innych, zwłaszcza za zmarłych, o czym można już przeczytać w Pierwszym Liście św. Pawła do Koryntian 15, 29: „Bo inaczej czegoż dokonają ci, co przyjmują chrzest za zmarłych? Jeżeli umarli w ogóle nie zmartwychwstają, to czemuż za nich chrzest przyjmują?”. Ten niejasny poniekąd fragment Pisma Świętego posłużył niektórym członkom grup religijnych, takich jak na przykład mormoni, do praktyki przyjmowania „chrztu”

${ }_{44}$ Por. J. Salij, Te dzieci nadal są nasze, „W Drodze” 5 (369) 2004, s. 124-126. 
w imieniu jakiejś osoby. Sens takiego działania zawiera się w przekonaniu, iż człowiek może dostąpić zbawienia, nawet jeśli za życia był grzesznikiem czy niewierzącym, wskutek przyjęcia chrztu przez kogoś innego w jego imieniu ${ }^{45}$. Wedle tej logiki można byłoby przyjmować taki „zastępczy chrzest" także za zmarłe nieochrzczone dzieci. Tymczasem doktryna katolicka od zawsze naucza, że sakramentów należy udzielać tylko żywym i tylko bezpośrednio. Ze względu na wymiar personalny sakramentu chrztu, w którym człowiek spotyka się bezpośrednio i osobiście z Chrystusem, nie jest możliwe ani udzielanie go drogą pośrednią komuś nieobecnemu czy już nieżyjącemu, ani przenoszenie skutków jego udzielenia na druga osobę. Sakrament obmycia odradzającego jako wyciskający niezatarty charakter może być zatem odzielony tylko raz, a jego skutki dotyczą tylko tej osoby, która go bezpośrednio przyjęła. Poza tym chrystologiczny i dialogiczny charakter sakramentów ustanowionych przez Boga zakłada wewnętrzną przemianę konkretnego człowieka, do którego Chrystus przychodzi z łaską i błogosławieństwem, działając realnie i niezawodnie. Nie można zatem manipulować sakramentem chrztu świętego wedle własnego upodobania, ponieważ po raz kolejny mielibyśmy do czynienia z myśleniem reifikującym i magicznym.

Jak widać, niektórych nawyków i błędnego myślenia nie udało się do końca uniknąć, jednak należy zwrócić uwagę na duży postęp, jaki dokonał się w powszechnym nauczaniu Kościoła i teologów, który przełożył się w znacznej mierze na praktykę chrześcijańskiego życia. We wszystkich tych sprawach należy szukać złotego środka. Współcześnie ogromna większość teologów, duchownych i świeckich nie widzi już powrotu do tezy o otchłani dzieci, a tym bardziej do tezy o najlżejszym cierpieniu w ogniu piekielnym. Nie można też jednak głosić, że z pewnością Bóg zbawi te dzieci ze względu na swe nieskończone miłosierdzie. Pewność dotyczy jedynie możliwości zbawienia, jaką Stwórca daje każdemu człowiekowi, jednak to, czy dziecko lub ktokolwiek inny skorzysta z tej szansy i sposób, w jaki może to uczynić, pozostaje tajemnicą, która odsłania się tylko Bogu i tej konkretnej osobie.

Chrześcijanie powinni uświadamiać sobie i innym, jak wielka jest waga i znaczenie sakramentu obmycia odradzającego oraz jak doniosła jest modlitwa wstawiennicza za wszystkich ludzi, zarówno podczas każdej mszy

45 Por. A. Wójtowicz, Bóg mormonów, Kraków 2003, s. 134. 
świętej, jak i prywatnie. Ich zadaniem jest również przedstawienie odpowiednich argumentów do uzasadnienia nadziei, jaką posiadają na Boże miłosierdzie i w konsekwencji na zbawienie nieochrzczonych małych dzieci, pomimo braku tego ważnego sakramentu.

Niezwykle pomocne w tym zakresie są: Pismo Święte, zwłaszcza fragmenty mówiące o dzieciach i o powszechności zbawienia, a także dokument Międzynarodowej Komisji Teologicznej Nadzieja zbawienia dla dzieci zmarlych bez chrztu. Ich lektura i analiza pozwoli nie tyle dawać świadectwo światu o nadziei na zbawienie i ufność w Boże miłosierdzie, ale przede wszystkim pozwoli zanurzyć się w bezbrzeżną głębię Bożej miłości, która obejmuje wszystkich ludzi i każdego człowieka z osobna.

\section{Summary}

The Fate of Infants Dying Without Baptism

- Unknown History and Contemporary Questions

The article presents a brief history of the question concerning the fate of infants who die without the sacrament of baptism. It includes both the theological dimension of this issue and its existential consequences. Such a presentation of the question serves to formulate responses to the ever-arising problems concerning the baptism of children, the lack of this sacrament, theological perplexities or pastors' and parents' behavior. The aim is also to understand that God loves and wills to save everyone, especially the smallest representatives of the human race who has no chance to be baptized.

Keywords: unbaptized children, baptism, salvation, limbus puerorum, original sin, burial

Słowa kluczowe: nieochrzczone dzieci, chrzest, zbawienie, limbus puerorum, grzech pierworodny, pogrzeb 